\title{
Vliv barometrického tlaku na úroveň hladiny vody v pozorovacích vrtech
}

\section{JAN KAŠPÁREK}

Klíčová slova: pozorovací vrt - barometrický tlak - podzemní voda

\section{SOUHRN}

Příspěvek se zabývá vlivem změn barometrického tlaku na úroveň hladiny vody ve vrtech a dalších pozorovacích sondách podzemních vod. Obsahuje rozbor souvisejících problémů při měření úrovně hladiny podzemní vody. Je uveden jednoduchý postup zjištění citlivosti hladiny v sondách na změny tlaku vzduchu pomocí ukazatele BE (barometric efficiency). Je ukázána interpretace velikosti a vlastností této citlivosti k systému sonda-kolektor a předloženo několik konkrétních príkladů pozorovacích sond s charakteristickými vlastnostmi.

\section{ÚVOD}

Ve Výzkumném ústavu vodohospodářském T. G. Masaryka, v. v. i., jsou od roku 2010 k měření výšky hladiny povrchové a podzemní vody používány snímače absolutního tlaku s kompenzací k barometrickému tlaku. Pro různé úkoly byla takto sledována hladina podzemní vody na více než třiceti objektech, především hydrogeologických vrtech, studních a důlních dílech. Ze získaných dat o hladinách podzemní vody a tlaku vzduchu bylo možno prakticky ověrit vliv barometrického tlaku na úroveň hladiny ve sledovaných objektech.

\section{ZPU゚SOBY MĚŘENÍ ÚROVNĚ HLADINY PODZEMNÍ VODY}

Prímé zjištění úrovně hladiny podzemní vody je možné různými hloubkovými sondami do povrchu zemského dosahujícími $k$ této hladině. Tyto sondy mohou být zhotovené a určené k sledování hladiny podzemní vody, tj. pozorovací vrty nebo podobná zařízení jako vrty hydrogeologické, vodárenské vrty a studny nebo objekty jiného původního určení, výkopy, těžební a důlní díla, popř. vhodné prírodní útvary.

Technickým provedením se sondy dělí na otevřené, kde je zjištována výška hladiny podzemní vody v sondě, a uzavřené, kde je do horninového prostředí umístěn od atmosféry izolovaný tlakoměr měřící tlak v kolektoru (uzavřený piezometr). K uzavřeným sondám patři také vrty s tlakovým zhlavím, ve kterých měříme tlak vody artéských zvodní. Dále popisovaná problematika vlivu barometrického tlaku na výšku hladiny se vztahuje k otevřeným sondám.

Hladinu měříme hladinoměry, které mohou být kontaktní, nebo tlakové. Kontaktní hladinoměry pro kontinuální záznam jsou plovákové nebo ultrazvukové, pro bodové měření se běžně používá pásmo se signalizací dosažení hladiny elektrickým kontaktem nebo akustickou píštalou. Měři se svislá vzdálenost od definovaného odměrného bodu k hladině.
Tlakové hladinoměry jsou tlakoměry absolutního tlaku nebo tlakoměry relativního tlaku s kompenzační kapilárou. Absolutní tlak je celkový tlak v kapalině (tj. hydrostatický a barometrický) a při měěení volné hladiny je třeba barometrický tlak od celkového tlaku v kapalině odečítat. Hladinoměry s kompenzační kapilárou porovnávají tlak kapaliny s barometrickým tlakem (v kabelu mezi záznamovou jednotkou a snímačem pod hladinou je kapilára pro vzduch). Tlakové hladinoměry měři tlak, resp. výšku vodního sloupce nad snímačem.

Nejvhodnější sondou pro sledování hladiny podzemní vody je pozorovací vrt, který je principem a provedením shodný s otevřeným piezometrem. Ten je na základě hydrogeologických dat předpokládaných a ověrených při vrtání technicky proveden ke sledování jedné konkrétní zvodně, se kterou je dobře hydraulicky propojen. Od ostatních kolektorů má být izolován. Perforace pažení vrtu je pod úrovní hladiny a prostor vrtu nad hladinou je ventilován do atmosféry.

\section{OVLIVNĚNÍ VÝŠKY HLADINY V SONDĚ BAROMETRICKÝM TLAKEM}

Úroveň hladiny v sondě je dána vyváženým stavem protichůdného tlaku vody a vzduchu v sondě. Tlak vody ve zvodni kromě režimu podzemní vody mohou ovlivňovat další jevy, známé jsou slapové a seismické vlivy, barometrický tlak určuje počasí. V ideálním pozorovacím vrtu je tlak vzduchu nad hladinou shodný s barometrickým tlakem a tlak vody je shodný s tlakem ve sledované zvodni.

Hladina vody $v$ sondách nesplňujících výše uvedené vlastnosti pozorovacího vrtu nemusí odpovídat hladině podzemní vody ve sledovaném kolektoru.

\section{HYDRAULIKA SONDY}

Pokud není sonda dobře hydraulicky propojena s kolektorem, může se změna hladiny projevit v sondě se zpožděním. Nemusí ani dojít k úplnému vyrovnání hladiny podzemní vody a hladiny v sondě, a zůstane trvalý rozdíl. Tento jev je dobře patrný při čerpací zkoušce, někdy se po čerpání hladina ustálí na mírně odlišné úrovni než před zkouškou, ta může být nižší i vyšší než výchozí stav.

Zpoždění změny hladiny vody $v$ sondě nastane také $v$ prrípadě objemnější sondy v kolektoru s malou propustností.

$\checkmark$ prípadě hydraulického propojení dvou nebo více kolektorů sondou a průtoku vody mezi kolektory je prakticky nemožné přesně určit vztah hladiny $v$ sondě k tlaku v kolektorech. Takovou sondu je možné použít k zjištění změn celkových bilančních poměrů, ale nelze ji použít k zjištění skutečné úrovně hladiny podzemní vody. Sonda může ovlivňovat poměry kolektorů trvalým propojením a průtokem vody mezi kolektory s odpovídající změnou tlaku (hladiny) 
nebo dočasně při vytvoření nebo zániku statické zásoby vody. Jev byl pozorován u některých vrtů, kdy po zřízení vrtu hladina po určitou dobu (i několik let) vykazovala trvalou klesající nebo stoupající tendenci.

\section{PNEUMATIKA SONDY}

K přenosu barometrického tlaku do vzduchu v sondě je potřeba dobré propojení sondy s atmosférou. Odvětrávací otvor sondy musí být dostatečný k rychlému přenesení změny tlaku do celého objemu vzduchu v sondě. Pokud je sonda částečně utěsněna od atmosféry, změna tlaku se projeví se zpožděním. Pokud je utěsněna zcela, tlak vody pưsobí proti tlaku stlačovaného vzduchu $\checkmark$ sondě a pohyb hladiny je menší než v otevřené sondě.

$\checkmark$ prípadě, kdy sonda propojí nesaturovanou zónu kolektoru s atmosférou (u vrtu perforace pažnice nad úrovní hladiny), a v kolektoru je pro vzduch propustné horninové prostředí, zvětšuje se objem vzduchu potřebný k přenesení změny barometrického tlaku do sondy (vrty, ze kterých při nízkém barometrickém tlaku trvale uniká vzduch, a při vysokém tlaku je vzduch nasáván). Barometrický tlak může v takové sondě pưsobit prímo na kolektor a měnit v něm tlakové poměry. Zvodeň s napjatou hladinou se v okolí sondy může změnit na zvodeň s volnou hladinou.

Při splnění výše uvedených parametrů pozorovacího vrtu působí změna barometrického tlaku vzduchu na vodní hladinu v sondě okamžitě, ale v kolektoru je odezva podle typu a hloubky kolektoru různá. V otevřených kolektorech je působení barometrického tlaku na zvodeň rychlé. Podle stupně izolace kolektoru se působení barometrického tlaku zmenšuje a prodlužuje se časová odezva, až ke kolektorům zcela izolovaným od atmosféry. Změna barometrického tlaku se v otevřených mělkých kolektorech přenáší ke zvodni půdním vzduchem, v částečně izolovaných kolektorech vzduchem a plyny v horninovém prostředí a hydraulicky.

Dojde-li ke změně poměru tlaků vody a vzduchu v sondě, změní se úroveň hladiny. Citlivost hladiny na změnu barometrického tlaku Ize podle [1] jednoduše popsat průměrnou hodnotou poměrů změn hladiny ke změnám tlaku vzduchu BE (barometric efficiency).

$$
\mathrm{BE}=\left(\sum(\mathrm{dHi} / \mathrm{dPi})\right) / \mathrm{n}
$$

kde dHi je změna úrovně hladiny [m] v časovém intervalu opakování měření $\mathrm{T}, \mathrm{dPi}$ je změna barometrického tlaku $\left[\mathrm{mH}_{2} \mathrm{O}\right] \vee$ časovém intervalu opakování měření $\mathrm{T}\left(1 \mathrm{kPa}=0,10197 \mathrm{mH}_{2} \mathrm{O}\right)$, $\mathrm{n}$ je počet posuzovaných změn.

Pro výpočet je možné použít pouze měření při změně barometrického tlaku. Vztah mezi změnou hladiny a změnou barometrického tlaku Ize také posoudit vynesením hodnot dH a dP do grafu, v kterém hodnota BE odpovídá sklonu proložené lineární regresní funkce. Na obr. 1 je grafické vynesení závislosti změny hladiny vody na změně tlaku vzduchu pro vrt V-28 při intervalu měření 1 hodina. Vrt V-28 Bučnice u Teplic nad Metují sleduje pískovcový kolektor $v$ hloubce $160-240 \mathrm{~m}$ a s hladinou kolem $15 \mathrm{~m}$ pod terénem.

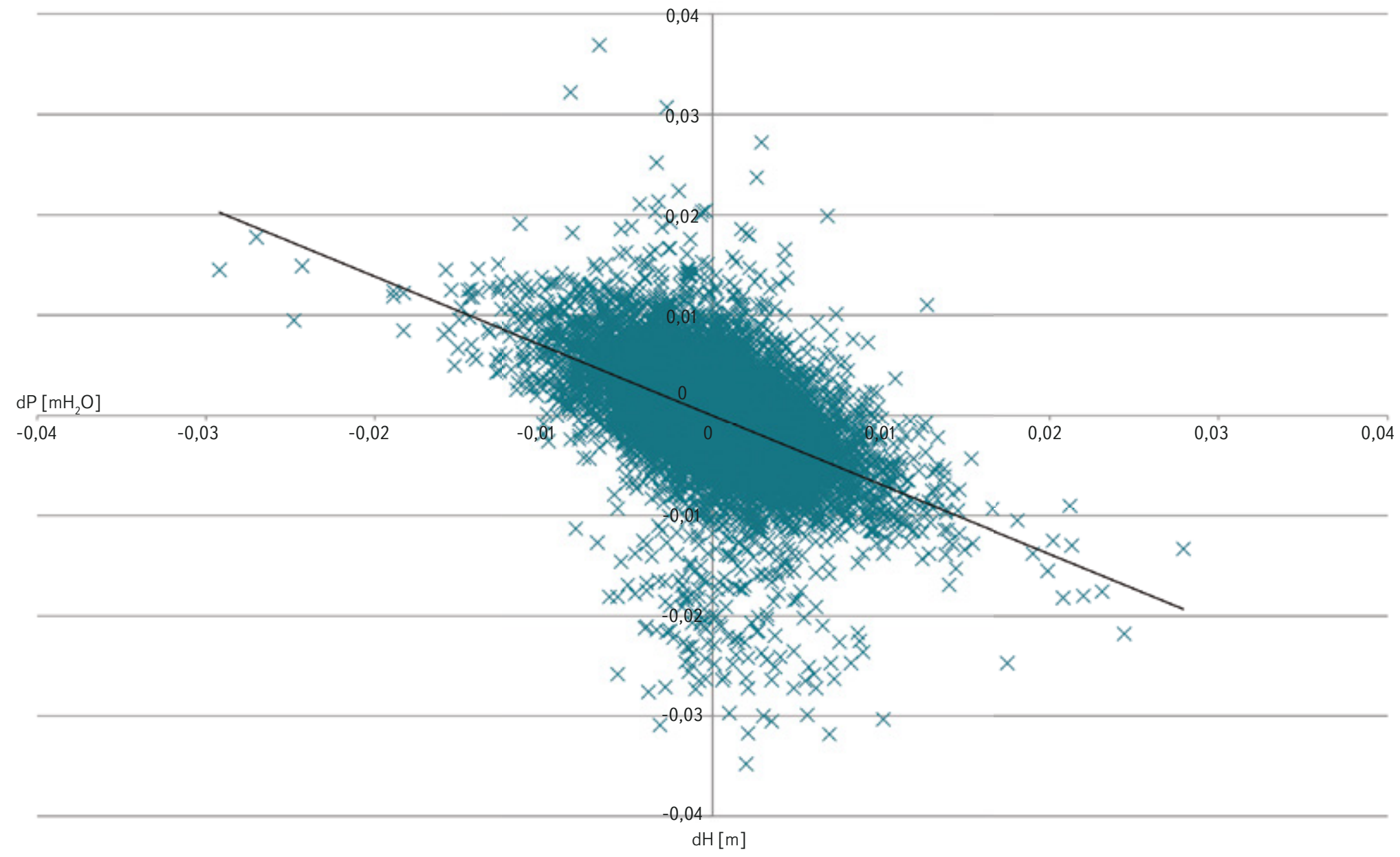

Obr. 1. Vrt V-28 Bučnice (polická křídová pánev), změna hladiny v závislosti na změně barometrického tlaku pro interval 1 hod, BE = -0,7

Fig. 1. Well V-28 Bucnice (Police Basin), level change depending on the change in barometric pressure for interval of $1 \mathrm{~h}, \mathrm{BE}=-0,7$ 


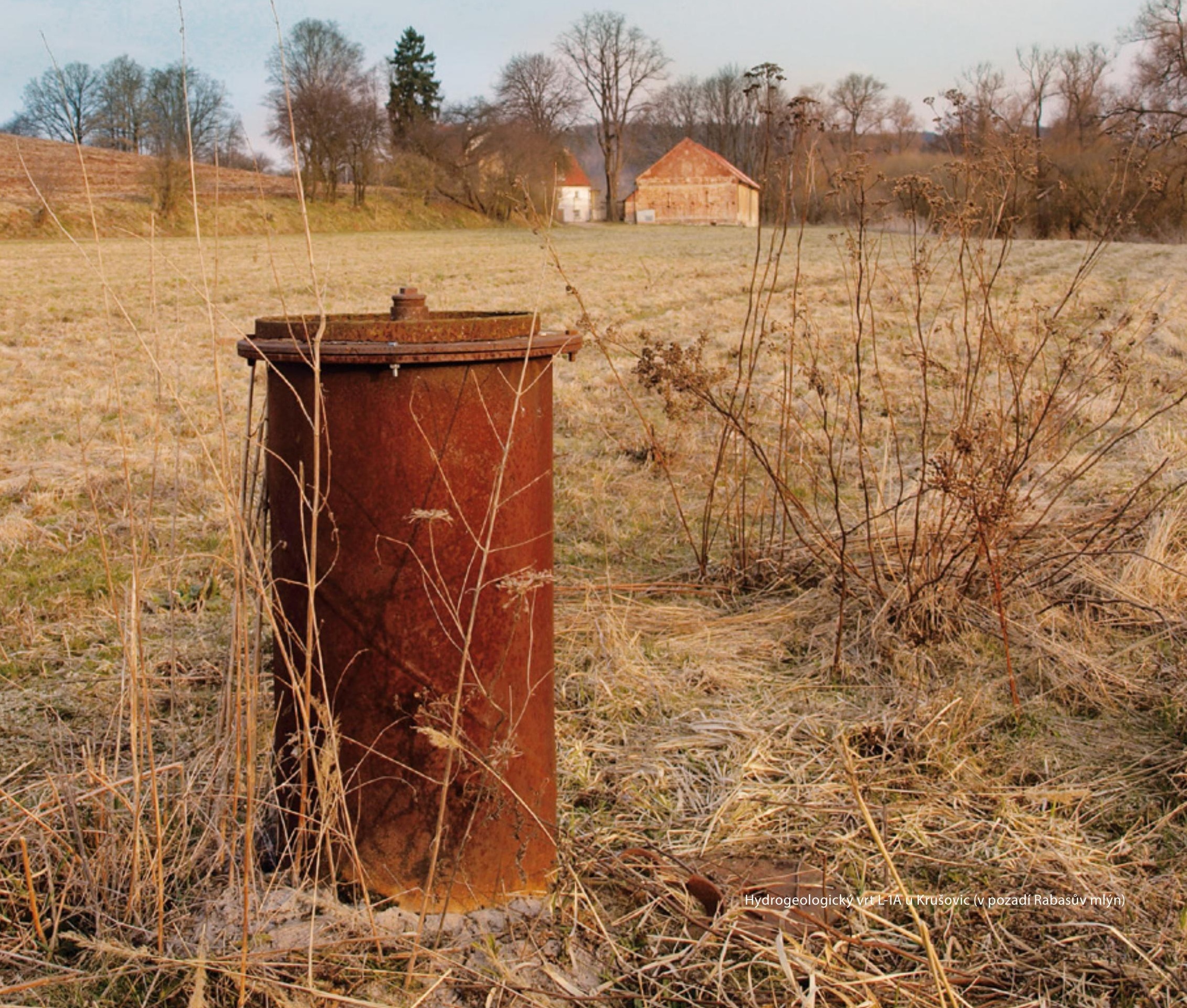


Podle zkušeností a provedených analýz je interval měření T pro zjištění míry citlivosti úrovně hladiny na změny barometrického tlaku vhodné zvolit v rozmezí deset minut až jedna hodina. Celková doba měření by měla být nejméně jeden měsíc, lépe je vyhodnotit celý hydrologický rok. Pro zpřesnění je možné vyřadit období významnějších dotací zásob podzemní vody.

Hodnota BE se při změně doby intervalu měření T mění, průběh této změny může doplnit informace o vztahu sondy a kolektoru. Na obr. 2 je hodnota BE pro vrt V-28 vynesena v závislosti na délce intervalu měření T.

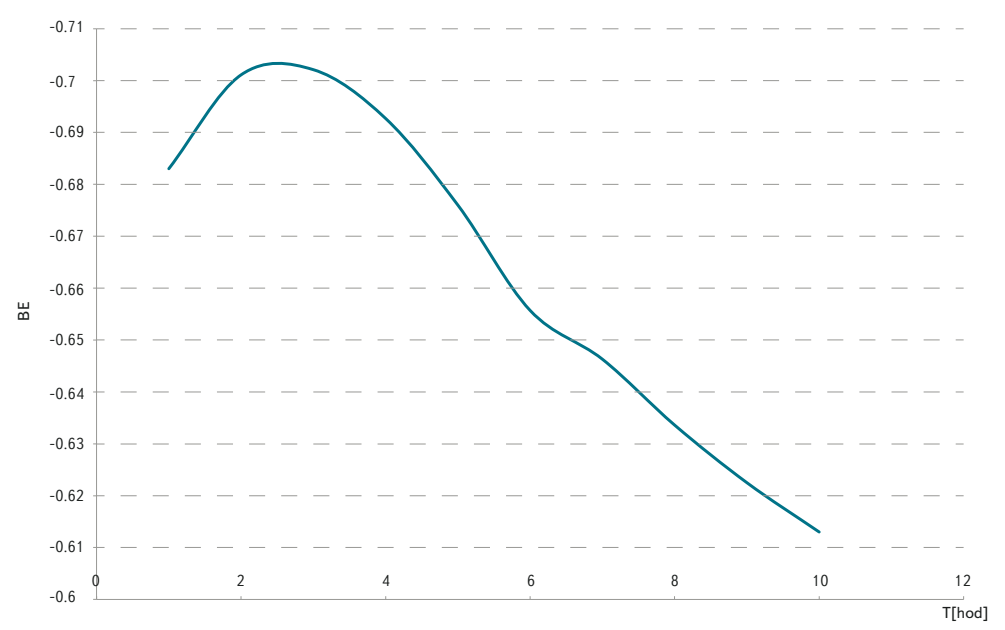

Obr. 2. Vrt V-28 Bučnice, průběh BE pro interval 1-10 hod

Fig. 2. Well V-28 Bucnice, course BE for interval 1-10 h

\section{INTERPRETACE HODNOT BE}

Běžná hodnota BE je v rozmezí 0 až -1.

Hodnoty BE nulové nebo blízké nule se vyskytují především u mělkých zvodní s volnou hladinou, tj. ve svrchních kolektorech neizolovaných od atmosféry, kde se změna barometrického tlaku projeví v kolektoru okamžitě. U hlouběji sledovaných hladin může nulová hodnota BE ukazovat na statickou zásobu vody v sondě, která nemá souvislost s vodou podzemní. Větší absolutní hodnota BE se vyskytuje u napjatých zvodní a hlouběji uložených kolektorů.

Klesá-li absolutní hodnota BE s prodlužujícím se intervalem měření T, jde o kolektor jen částečně propojený s atmosférou, a změna barometrického tlaku se v kolektoru projevuje se zpožděním. U kolektorů více izolovaných od atmosféry klesá absolutní hodnota BE pomalu a ovlivnění hladiny v sondě změnou barometrického tlaku je výraznější.

Jestliže absolutní hodnota BE je malá, při krátkém intervalu T a při jeho prodloužení se zvětšuje, naznačuje to malou hydraulickou propustnost hornin kolektoru nebo špatné propojení sondy s kolektorem. Je třeba delší doba k výměně vody mezi sondou a kolektorem.

Přičinou kladné hodnoty BE může být od atmosféry utěsněné zhlaví vrtu u zvodnění s volnou hladinou podzemní vody.

\section{CHYBA MĚŘENÍ ZPU゚SOBENÁ ZANEDBÁNÍM VLIVU ATMOSFÉRICKÉHO TLAKU}

Maximální pohyb hladiny způsobený vlivem změny barometrického tlaku maxdHp odpovídá součinu maximálního rozdílu hodnot barometrického tlaku maxdP a citlivosti BE.
$\operatorname{maxdHp}=|B E| . \operatorname{maxdP}$

Z měření barometrického tlaku na různých místech České republiky v období 2012-2015 bylo vyhodnoceno maximální rozpětí kolísání barometrického tlaku (při vyřazení $10 \%$ krajních hodnot) maxdP $=0,25 \mathrm{~m}$. Zjednodušeně tedy $\operatorname{maxdHp}=|\mathrm{BE}|$. 0,25.

Pro hydrogeologické vrty sledující hlouběji položené kolektory jsou běžné hodnoty BE kolem -0,5. Pokud nemáme $k$ dispozici měření barometrického tlaku, resp. zjištěnou hodnotu BE, můžeme předpokládat pohyb hladiny vlivem změn barometrického tlaku přibližně 0,12 m. Ze stejného důvodu je doporučeno ve studii [1] při čerpací zkoušce snížit hladinu nejméně o 0,2 m.

Z praktického hlediska je důležité, v jakém poměru jsou změny hladiny způsobené změnami tlaku vzduchu k celkovému kolísání hladiny. Jako měřítko můžeme použít poměr D [\%], který predstavuje maximální chybu měření hladiny, které se můžeme dopustit zanedbáním vlivu změn atmosférického tlaku.

$$
D=\operatorname{maxdHp} / \operatorname{maxdH} \times 100
$$

kde maxdH je rozsah kolísání hladiny $v$ sondě a maxdHp je rozsah kolísání hladiny $v$ sondě způsobený změnou atmosférického tlaku.

Pro posouzení vlivu chyby měření zpưsobené citlivostí na barometrický tlak je vhodné porovnat skutečný průběh hladiny s modelovou řadou získanou ze změřených hodnot barometrického tlaku a hodnoty BE. Na obr. 3 a 4 je skutečný průběh hladiny $\mathrm{H}$ a modelový průběh $\mathrm{Hm}$ pro vrty V-28 a HM-1.

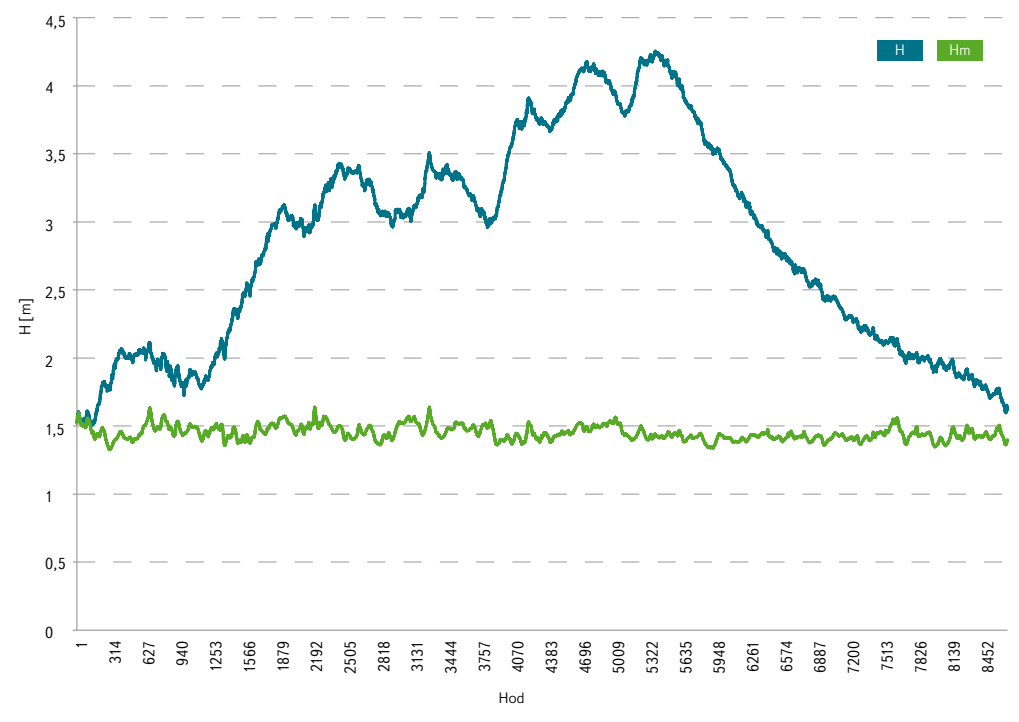

Obr. 3. Vrt V-28 Bučnice, pozorovaný průběh hladiny H a modelované kolísání hladiny vlivem změn tlaku vzduchu Hm pro rok 2013

Fig. 3. Well V-28 Bucnice, observation of the levels $\mathrm{H}$ and modeled level fluctuations due to changes in air pressure, 2013

U vrtu V-28 je patrný pohyb hladiny vlivem změn barometrického tlaku, který pouze moduluje celkový průběh hladiny. Tomu odpovídá poměrně malá možná chyba v měření $\mathrm{D}=4 \%$.

Vrt HM-1 je krajním prípadem, kde pohyb hladiny vlivem změn barometrického tlaku je dominantní. Maximální možná chyba v měření zde dosahuje až $\mathrm{D}=40 \%$.

Při občasném nebo pravidelném bodovém měření hladiny $v$ delších časových intervalech je tedy třeba zvážit vliv této chyby, popř. upravit režim pozorování. 




Obr. 4. Vrt HM-1 Měcholupy, pozorovaný průběh hladiny H a modelované kolísání hladiny vlivem změn tlaku vzduchu Hm v období 3. 2012-12. 2012

Fig. 4. Well HM-1 Mecholupy, observation of the levels $\mathrm{H}$ and modeled level fluctuations due to changes in air pressure, 3. 2012-12. 2012

\section{PŘÍKLADY RŮZNÝCH OBJEKTU゚ S CHARAKTERISTICKÝM BE}

Důlní dílo Ejpovice u Rokycan, ražené v pevné břidlici (Barrandien), hladina přibližně ve 20 m pod terénem, ověřována možnost použití jako vodního zdroje. Hladina zcela stabilního průběhu, hodnota $\mathrm{BE}=0$. Čerpací zkouškou bylo prokázáno, že jde o statickou zásobu vody nepropojenou s žádným kolektorem, dotovanou občasným prítokem z nadloží.

Mělká studna na hřbitově v Kněževsi u Rakovníka, zděná kamenem, hladina približně $6 \mathrm{~m}$ pod terénem. Hodnota BE = -0,04 ( 11 hod). Studna ve svrchním kvarterním kolektoru se zvodní dotovanou srážkami. Maximální chyba měření vlivem barometrického tlaku $\mathrm{D}=0,3$ \% celkového rozpětí kolísání.

Pozorovací vrt V-28 Bučnice u Teplic nad Metují, hladina přibližně 15 m pod terénem, sledující turonský kolektor v pískovci, v hloubce 160-240 m [2]. BE pro interval T 1 hod je -0,68 a dále mírně klesá, viz obr. 2. Napjatá zvodeň je více izolovaná od atmosféry s výrazným režimovým chodem hladiny (obr. 3). Maximální chyba měěení vlivem barometrického tlaku je $\mathrm{D}=4 \%$ celkového rozpětí kolísání.

Hydrogeologický vrt HM-1 u Měcholup u Žatce, hladina přibližně 34 m pod terénem, sledující kolektor v cenomanských pískovcích v hloubce 35-120 m [3]. Hodnota citlivosti BE je -0,41 pro interval měření v rozmezí T 1-48 hod. Napjatá zvodeň izolovaná od atmosféry s pomalým režimem chodu hladiny. Maximální chyba měření vlivem barometrického tlaku je $D=40 \%$ celkového rozpětí kolísání.

\section{ZÁVĚR}

Na hladinu vody $v$ sondách do svrchních kolektorů s volnou hladinou podzemní vody mají změny barometrického tlaku zanedbatelný vliv.

U sond sledujících napjaté zvodně a sond do hlouběji uložených kolektorů se zvodněmi napjatými i volnými je patrný vliv barometrického tlaku na hladinu, který Ize statisticky vyjádřit citlivostí BE. Důsledkem zanedbání vlivu barometrického tlaku dochází ke zvětšení chyb měření úrovně podzemní vody v kolektoru sondou. Kromě chyby měření hladiny může být pohyb hladiny v sondě vlivem změny barometrického tlaku myIně považován za skutečnou změnu tlaku ve zvodni. Pokles tlaku při přechodu frontálního systému způsobí rychlý nárůst hladiny, který nabízí chybnou interpretaci dotace zvodně srážkami. Podobnost či shodnost průběhu hladiny vlivem změn barometrického tlaku $v$ různých objektech může vést k chybnému závěru sledování stejné zvodně.

Další možnosti využití znalosti citlivosti hladiny v sondě na barometrický tlak:

- pokud je kolektor sledován vhodným pozorovacím vrtem, je možné z analýzy BE získat doplňující informace o kolektoru;

- při sledování kolektoru sondou neznámých nebo nevhodných parametrů Ize rozborem hodnoty BE upresnit vztah sondy a kolektoru;

- při odběru vzorku podzemní vody ze sondy citlivé na změnu barometrického tlaku napomáhá proudění vody mezi sondou a zvodní způsobené pohybem hladiny k výměně vody v sondě.

\section{Literatura}

[1] FILECCIA, A. Correcting water level data for barometric pressure fluctuations, 2011. Dostupné z: wwW. filecciageologia.it.

[2] DEBEFEROVÁ, A., KNĚŽEK, V. a NEJEDLÝ, M. Polická pánev - Teplicko - Hydrogeologický průzkum za I. etapu, výzkumná zpráva, Praha: Vodní zdroje, 1990.

[3] ČERNÁ, J. a ŽlŽKKA, V. Hydrogeologický průzkum - závěrečná zpráva Měcholupy u Žatce, výzkumná zpráva, Praha: Vodní zdroje, 1981.

\section{Autor}

Jan Kašpárek

凶jan_kasparek@vuv.cz

Výzkumný ústav vodohospodářský T. G. Masaryka, v. v. i., Praha

Príspěvek prošel lektorským řízením.

\section{INFLUENCE OF BAROMETRIC PRESSURE ON THE WATER LEVEL AT THE OBSERVATION WELLS}

\section{KASPAREK, J.}

TGM Water Research Institute, p. r. i.

Keywords: observation wells - barometric pressure - groundwater

The article deals with the influence of barometric pressure changes on water levels in monitoring wells and other groundwater observation boreholes. An analysis of the problems involved in measuring the groundwater level was performed. A simple procedure to determine the sensitivity of water level in the boreholes to changes in air pressure using BE indicators (barometric efficiency) is introduced. The interpretation of the size and characteristics of the sensitivity of the borehole-aquifer system is shown and some concrete examples of observation wells characteristics are presented. 